\title{
"Analisis Kesehatan Bank dengan Metode Non-Performing Loan Dan Metode CAMEL" Studi kasus: PT. Bank Perkreditan Rakyat Bumidhana - Tangerang
}

\author{
Tri Endi Ardiyansah.P.S, S.E, M.M \\ Dosen Politeknik LP3I Jakarta \\ Imda Hayati \\ Alumni FEB - universitas Muhammadiyah Tangerang
}

\begin{abstract}
The purposes of the research are to find some factors influenced to non-performing loan at PT. BPR Bumidharma-Tangerang. This study used descriptive quantitative design. Data collection employed three ways that are observation, interviews, and librarian data collection. As data seconder is documentation. The result showed that root-case of non-performing loan is total un-current credit value in this bank.

In the real practical, non-performing loan divided by 4(four) category that are current by outstanding, un-current, missing-Debt, un-collectable. Based on Financial report, NPL ratio over than 5\% from BI regulation, here indicated non-wealth condition. By CAMEL factor, two ratios indicated non-wealth that are Risk \& management ratio that gain 53\% and ROA ratio is $0,55 \%$ below than $0,765 \%$ as standard. There are some Obstacles and weakness in corporate management. First, there isn't SOP implemented in company. Second, Corporate management always grant special credit service to employee without screening \& analyze above it.
\end{abstract}

Keywords: Non-performing loan, CAMEL method, Ratio

\begin{abstract}
ABSTRAK
Penelitian ini bertujuan untuk mengetahui faktor-faktor yang mempengaruhi non performing loan pada PT. BPR Bumidhana. Penelitian ini menggunakan desain penelitian deskriptif kuantitatif. Pengumpulan data dilakukan dengan tiga cara yaitu wawancara, observasi dan studi pustaka data yang digunakan meliputi data sekunder yaitu berupa dokumentasi. Hasil penelitian menunjukkan bahwa penyebab timbulnya Non Performing Loan pada PT. BPR Bumidhana adalah nilai total kredit bermasalah.
\end{abstract}


Pada prakteknya, Kredit bermasalah dikategorikan menjadi 4 (empat) jenis yaitu lancar dengan tunggakan, kurang lancar, diragukan dan macet. Berdasarkan laporan tingkat kesehatan bank, rasio NPL dinyatakan tidak sehat karena melebihi batas maksimal 5\% dari ketentuan Bank Indonesia. Semua rasio dari faktor CAMEL mendapat predikat sehat kecuali Rasio Manajeman Umum dan Resiko dengan nilai rasio sebesar $53 \%$ pada posisi nilai acuan 51-66\% da rasio ROA pada faktor Rentabilitas dengan nilai $0,55 \%$ pada posisi nilai acuan kurang dari 0,765\%. Beberapa hambatan dan kelemahan pada PT. BPR Bumidhana adalah belum diterapkan SOP (Standard Operating Procedure) dan belum memiliki aturan-aturan baku perusahaan lainnya serta manajemen terlalu gampang untuk memberikan kredit bagi karyawan tanpa ada analisis yang kuat.

\section{Kata Kunci : Non-performing loan, metode CAMEL, Rasio}

\section{PENDAHULUAN}

\section{Latar Belakang Masalah}

Pada awal tahun 2008 terjadi krisis keuangan yang berawal di Amerika Serikat yang menjalar ke pasar financial global, pada bulan Maret 2008 Bank Amerika Serikat J.P Morgan Chase terpaksa membantu bank investasi Bear Stearns yang merugi akibat spekulasi hipotek rumah.

Dari kejadian ini pemerintah menegaskan pentingnya penilaian tingkat kesehatan bank yang dituangkan dalam Undang-Undang Republik Indonesia Nomor 10 Tahun 1998 tanggal 10 November 1998 pasal 29 ayat 2 yang menyatakan bahwa bank wajib memelihara tingkat kesehatan bank sesuai dengan ketentuan kecukupan modal (Capital), kualitas aktiva (asset), kualitas manajemen (management), rentabilitas (Earning) likuiditas (liquidity), atau disingkat dengan istilah CAMEL.

Dalam proses pemberian kredit ,Non Performing Loan merupakan presentase jumlah kredit bermasalah terhadap total kredit yang disalurkan bank, kredit bermasalah menurut bank Indonesia merupakan kredit yang digolongkan ke dalam kolektabilitas Kurang Lancar (KL), Diragukan (D) dan Macet (M). Rasio ini menunujukan kemampuan manajemen bank dalam mengelola kredit bermasalah yang diberikan oleh bank. NPL yang tinggi menyebabkan timbulnya masalah likuiditas (ketidakmampuan membayar 
dana pihak ketiga), rentabilitas (utang tidak bisa ditagih) ataupun solvabilitas (modal berkurang) dan rasio-rasio keuangan lainnya.

PT. Bank Perkreditan Rakyat Bumidhana adalah salah satu badan usaha perseroan terbatas yang usahanya bergerak dibidang perbankan, yang mempunyai tujuan berperan secara aktif dalam bidang perbankan guna mendukung kebijakan pemerintah dalam membantu pembiayaan dan pengembangan usaha mikro, kecil dan menengah serta mempunyai struktur keuangan yang sehat dan memberikan konstribusi yang optimal dengan tetap berpedoman kepada Undang-undang dan peraturan yang berlaku.

\section{LANDASAN TEORI}

\section{A. Tingkat Kesehatan Bank}

Undang-undang Nomor 10 tahun 1998 jo. UU No.7 Tahun 1992 tentang perbankan, pengawasan dan pembinaan bank menegaskan bahwa bank wajib memelihara tingkat kesehatan bank sesuai dengan ketentuan kecukupan modal, kualitas aset, kualitas manajemen, likuiditas, rentabilitas, solvabilitas dan aspek lainnya yang berhubungan dengan usaha bank, dan wajib melakukan kegiatan usaha sesuai dengan prinsip kehatihatian. Frianto Pandia (2012) mengatakan bahwa kesehatan suatu bank merupakan Kepentingan semua pihak yang terkait. Bank-bank yang sehat akan mempengaruhi sistem perekonomian suatu Negara secara menyeluruh. Oleh karenanya bank perlu dinilai kesehatannya. Sofyan Basir (2012) mengatakan penilaian tingkat kesehatan bank dimaksudkan sebagai Tolok ukur bagi manajemen bank untuk menilai apakah pengelolaan bank dilakukan sejalan dengan asas perbankan yang sehat dan sesuai dengan ketentuan yang berlaku, juga untuk menetapkan arah pembinaan dan pengembangan bank secara keseluruhan. Gubernur Bank Indonesia melalui SK No. 30/12/KEP/DIR tanggal 30 April 1997 tentang Tatacara Penilaian Tingkat Kesehatan Bank Perkreditan Rakyat, diuraikan seperti pada table dibawah:

\begin{tabular}{|l|c|c|}
\hline \multicolumn{1}{|c|}{ Aspek CAMEL } & Rasio Keuangan & Bobot \\
\hline CAPITAL & CAR & $30 \%$ \\
\hline \multirow{2}{*}{ KUALITAS AKTIVA PRODUKTIF } & KAP & $25 \%$ \\
\cline { 2 - 3 } & PPAP & $5 \%$ \\
\hline \multirow{2}{*}{ MANAJEMEN } & Umum & $10 \%$ \\
\cline { 2 - 3 } & Resiko & $10 \%$ \\
\hline
\end{tabular}




\begin{tabular}{|l|c|c|}
\multirow{2}{*}{ RENTABILITAS } & ROA & $5 \%$ \\
\cline { 2 - 3 } & BOPO & $5 \%$ \\
\hline \multirow{2}{*}{ LIKUIDITAS } & CR & $5 \%$ \\
\cline { 2 - 3 } & LDR & $5 \%$ \\
\hline
\end{tabular}

Tabel 1 Penilaian Tingkat Kesehatan BPR SAK ETAP

Sumber : Bank Indonesia, 1997

Dari uraian diatas, penilaian tingkat kesehatan bank dilakukan dengan sistem kredit yang dinyatakan dengan nilai kredit 0 s/d 100. Predikat Sehat nilai kreditnya 81 100, Cukup sehat nilai kreditnya 66 - <81, Kurang sehat nilai kreditnya 51 - < 66 dan tidak sehat nilai kreditnya $00-<51$.

Hal di atas juga dikemukakan oleh Sarwono Sudarto (2012) bahwa tingkat kesehatan bank akan tergantung atau diturunkan menjadi tidak sehat. Kasmir (2012:113) memberikan penjelasan bahwa suatu usaha perbankan sangatlah dipengaruhi oleh jumlah kredit yang disalurkan dalam suatu periode. Peraturan BI No.:13/26/PBI/2011 tentang perubahan atas Peraturan BI No.: 8/19/PBI/2006 tentang Kualitas Aktiva Produktif dan Pembentukan Penyisihan Penghapusan Aktiva Produktif Bank Perkreditan Rakyat (BPR) dikolompokdan dalam 4 golongan yaitu Lancar, Kurang Lancar, Diragukan dan Macet.

\section{B. CAMEL}

Pada dasarnya penilaian tingkat kesehatan BPR mencakup penilaian terhadap faktorfaktor CAMEL(permodalan, kualitas aktiva produktif, manajemen, rentabilitas, dan likuiditas) dengan menggunakan pendekatan kualitatif terhadap komponen-komponen tersebut.Arifiandy Permata Veithsal (2012:470) menjelaskan faktor-faktor CAMEL sebagai berikut.

\section{Permodalan (Capital)}

Modal adalah faktor penting bagi bank dalam rangka pengembangan usaha dan menampung kerugian. Permodalan merupakan penilaian terhadap kecukupan modal bank untuk mengcover eksposur saat ini dan mengantisipasi eksposur resiko di masa datang.

2. Kualitas Aktiva Produktif (Asset Quality)

Aset Produktif adalah penanaman dana pada pihak terkait dan pihak tidak terkait, 
Penilaian kualitas aset merupakan penilaian terhadap kondisi aset bank dan kecukupan manajemen resiko kredit.

3. Manajemen (management)

Manajemen digunakan untuk memastikan kualitas dan tingkat kedalaman penerapan prinsip manajemen yang sehat, terutama yang terkait dengan manajemen umum dan manajemen resiko

4. Rentabilitas (Earnings)

Earnings digunakan untuk memastikan efisiensi dan kualitas pendapatan bank secara benar dan akurat, kelemahan dari sisi pendapatan riil merupakan indikator potensi masalah bank. Penilaian Faktor Rentabilitas dilakukan dengan pendekatan Kualitatif dan kuantitatif terhadap komponen-komponen berikut ini:

1) Imbal hasil atas aset (return of assets - ROA)

$$
\text { ROA }=\frac{\text { Laba Sebelum Pajak }}{\text { Total Aktiva }} \times 100 \%
$$

2) Imbal hasil atas ekuitas (return of equity - ROE)

$$
\text { ROA }=\frac{\text { Laba Setelah Pajak }}{\text { Total Aktiva }} \times 100 \%
$$

3) Margin Bunga Bersih (net interest margin - NIM)

$$
\mathrm{NIM}=\frac{\text { Pendapatan Bersih }}{\text { Aktiva Produktif }} \times 100 \%
$$

4) Biaya operasional terhadap pendapatan operasional (BOPO)

$$
\text { BOPO }=\frac{\text { Biaya }(\text { Beban }) \text { Operasional }}{\text { Pendapatan Operasional }} \times 100 \%
$$

5) Pendapatan Operasional diluar bunga FBIR (Fee Base Income Ratio)

$F B I R=\underline{\text { Pendapatan Operasional (selain bunga) }} \times 100 \%$ Pendapatan Operasional 


\section{Likuiditas (Liquidity)}

Likuiditas digunakan untuk memastikan dilaksanakannya manajemen aset dan kewajiban dalam menentukan dan menyediakan likuiditas yang cukup. Penilaian likuiditas merupakan penilaian terhadap kemampuan bank untuk memelihara dan memenuhi kebutuhan likuditas yang memadai dan kecukupan manajemen risiko likuiditas.

\section{Non Performing Loan}

NPL merupakan salah satu rasio keuangan yang berpengaruh terhadap Tingkat Kesehatan suatu Bank, rasio NPL dihitung berdasarkan total saldo kredit bermasalah terhadap total kredit.

$$
N P L=\frac{\text { Kredit Bermasalah }}{\text { Total Kredit }}
$$

Rasio NPL dibagi menjadi dua yaitu NPL Gross dan NPL Netto, perhitungan NPL gross dihitung dengan mengabaikan perhitungan PPAP pada kredit bermasalah, sedangkan NPL Netto dihitung dengan mengurangi Saldo Kredit Bermasalah dengan perhitungan PPAP yang telah dibentuk.

\section{Performing Loan}

Kredit dapat dikatakan lancar apabila tidak terjadi tunggakan angsuran pokok dan/atau bunga selama tiga kali periode pembayaran secara berturut-turut. Menurut Kasmir (2012:107) suatu kredit dapat dikatakan lancar apabila:

a. Pembayaran angsuran pokok dan/atau bunga tepat waktu.

b. Tidak terdapat tungakan pembayaran angsuran pokok dan/atau bunga yang belum melampaui 90 hari.

c. Memiliki mutasi rekening yang aktif.

d. Bagian dari kredit yang dijamin dengan agunan tunai (cash collateral).

Dalam perhitungan PPAP Kredit lancar ditetapkan sebesar 0,5\% dari sisa pinjaman pokok. Namun hal ini dikecualikan apabila agunan yang dijaminkan bersifat likuid berupa SBI, surat utang yang dikeluarkan pemerintah RI, tabungan dan/atau deposito yang diblokir pada BPR yang bersangkutan disertai dengan surat kuasa pencairan. 


\section{METODOLOGI PENELITIAN}

\section{Objek dan Subjek Penelitian}

Objek dalam penelitian ini adalah kesehatan bank dengan metode CAMEL dan Non Performing Loan sedangkan yang menjadi subjek dalam penelitian ini adalah PT. Bank Perkreditan Rakyat Bumidhana - Tangerang. Penelitian ini merupakan penelitian lapangan ( field Research) dimana data data yang diperoleh penulis adalah hasil observasi langsung ke objek penelitian.

\section{Jenis Data}

Dalam penelitian ini data yang digunakan adalah data sekunder berupa dokumen pada objek penelitian, yang dikumpulkan oleh penulis dengan menggunakan metode kepustakaan yaitu dengan cara mengumpulkan data data dari literatur dan buku buku yang berhubungan dengan objek penelitian sedangkan dokumen dokumen didapat dari sumbernya yang menjadi subjek dalam penelitian

\section{Tehnik Pengumpulan Data}

Adapun teknik pengumpulan data yang digunakan dalam penelitian ini adalah:

Observasi, yaitu mengadakan penelitian dilapangan untuk memperoleh data-data yang diperlukan serta melakukan pengamatan secara langsung terhadap masalah yang dihadapi di lapangan. Interview, tanya jawab yang dilakukan dengan pihak-pihak terkait dengan objek penelitian. Studi Pustaka, yaitu metode yang dilakukan dengan cara mempelajari teori dan penelitian terdahulu yang terkait dengan penelitian ini.

\section{HASIL PENELITIAN DAN PEMBAHASAN}

Dari penelitian didapatkan faktor-faktor yang mempengaruhi Non Performing Loan adalah jumlah kredit bermasalah pada bank, jumlah kredit yang disalurkan oleh bank dan PPAP yang telah dibentuk oleh bank, Berikut ini terlampir tabel perhitungan Non Performing Loan pada PT. BPR Bumidhana per tanggal 31 Maret 2017.

\begin{tabular}{|l|c|c|c|}
\hline \multirow{2}{*}{ KETERANGAN } & \multicolumn{3}{|c|}{$\begin{array}{c}\text { Pencapaian KInerja } \\
\text { (dalam ribuan rupiah) }\end{array}$} \\
\cline { 2 - 4 } & \multirow{2}{*}{ Kredit } & $\begin{array}{c}\text { Penempatan pada Bank } \\
\text { Lain Selain Giro }\end{array}$ & Jumlah \\
\hline AKTIVA PRODUKTIF & \multicolumn{3}{|c|}{} \\
\hline - Lancar & 24.022 .293 & 3.151 .249 & 27.173 .542 \\
\hline - Kurang lancer & 210.988 & & 210.988 \\
\hline - Diragukan & 124.450 & & 124.450 \\
\hline - Macet & 1.079 .665 & & 1.079 .665 \\
\hline
\end{tabular}




\begin{tabular}{|c|c|c|c|}
\hline JUMLAH & 25.437 .395 & 3.151 .249 & 28.588 .644 \\
\hline \multicolumn{4}{|l|}{$\begin{array}{l}\text { PPAPWD } \\
\text { (setelah diperhitungkan agunan) }\end{array}$} \\
\hline - Lancar $(0,5 \%)$ & 9.099 & 15.756 & 24.855 \\
\hline $\begin{array}{l}\text { - Kurang lancar } \\
(10 \%)\end{array}$ & 14.139 & & 14.139 \\
\hline - Diragukan (50\%) & - & & - \\
\hline - Macet $(100 \%)$ & 50.784 & & 50.784 \\
\hline JUMLAH & 74.021 & & 89.778 \\
\hline Jumlah Kredit Bermasalah & \multirow{3}{*}{\multicolumn{2}{|c|}{$\begin{array}{l}\text { NPL Bruto } \\
\text { Rasio NPL Bruto } \\
\text { NPL Netto }\end{array}$}} & 1.415 .103 \\
\hline Jumlah Kredit & & & $5,56 \%$ \\
\hline Jumlah Kredit Bermasalah-PPAP & & & 1.350 .180 \\
\hline Jumlah Kredit & \multicolumn{2}{|c|}{ Rasio NPL Netto } & $5,31 \%$ \\
\hline
\end{tabular}

Tabel 2 Rasio Non Performing Loan

Sumber : PT. BPR Bumidhana, 2017

Dari tabel di atas dapat dilihat bahwa Rasio NPL Netto PT. BPR Bumidahana pada periode Maret 2016 sebesar 5,31\% lebih dari 5\% batas maksimum yang ditentukan oleh Bank Indonesia, maka rasio NPL PT. BPR Bumidhana pada periode Maret 2017 dikatakan tidak sehat. Berikut ini rumus perhitungan Rasio NPL Netto:

\section{NPL Netto $=\underline{(\text { Akt.ProduktifKL }+D+M)(P P A P ~ K L+D+M)} \times 100 \%$ Jumlah Kredit$$
\frac{(210.988+124.450+1.079665)-(14.139+0+50.784)}{25.437 .395} \times 100 \%=5,31 \%
$$

Dari rasio NPL ini dapat disimpulkan bahwa kurang maksimalnya kinerja Divisi Marketing dan Divisi Remidial. Untuk melakukan perhitungan CAMEL data yang digunakan dalam perhitungan diambil dari laporan keuangan bank, dibawah ini adalah tabel Laporan Keuangan Neraca dan Laba Rugi PT. BPR Bumidhana Periode 31 Maret 2017:

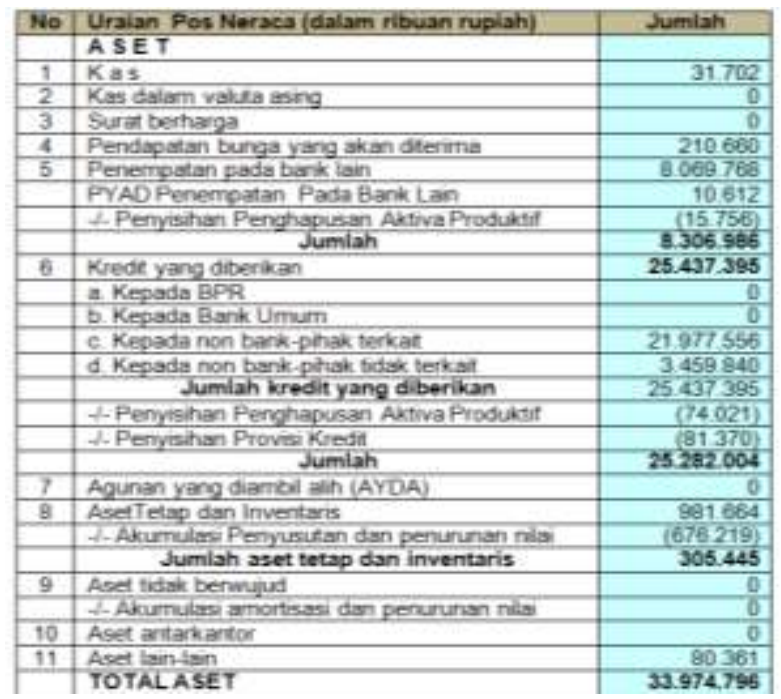

Tabel 3 Laporan Keuangan Neraca Sumber : PT. BPR Bumidhana, 2017

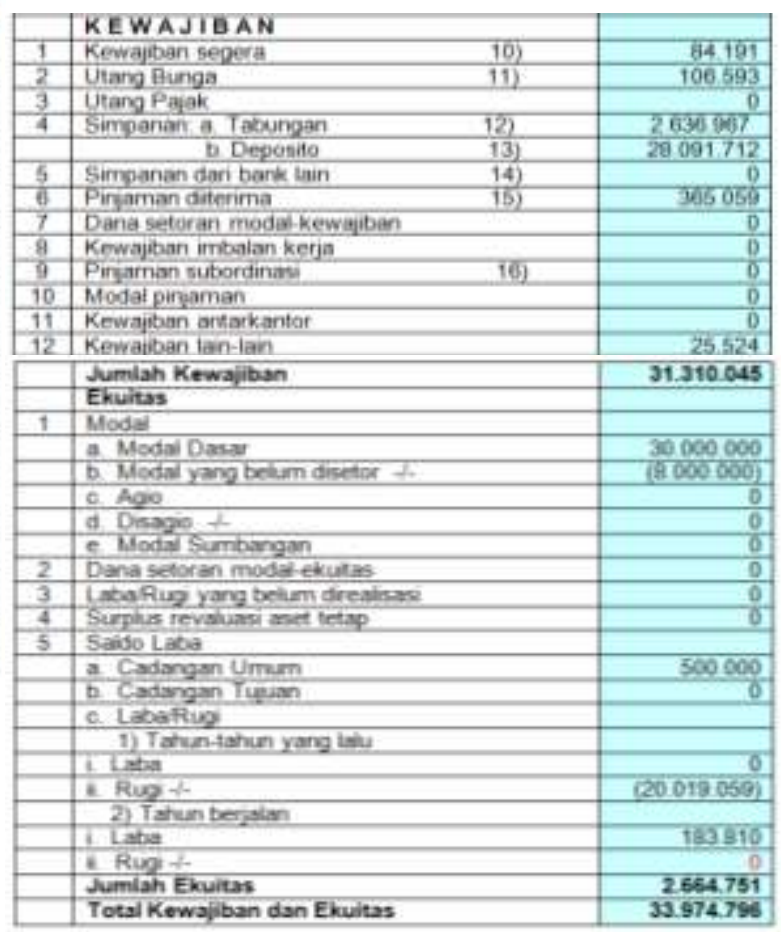




\begin{tabular}{|c|c|}
\hline Uraian Pos Laba Rugi (dalam ribuan rupiah) & Jumlah \\
\hline A. Pendapatan Operasional & 1.272 .857 \\
\hline \multicolumn{2}{|l|}{ 1. Pendapatan Bunga } \\
\hline \multicolumn{2}{|l|}{ a. Bunga kontraktual } \\
\hline i. Surat berharga & 0 \\
\hline \multicolumn{2}{|l|}{ i. Penempatan pada bank lain } \\
\hline Giro & 15.741 \\
\hline Tabungan & 10 \\
\hline Deposito & 78.572 \\
\hline Sertifikat deposito & 0 \\
\hline \multicolumn{2}{|l|}{ iii. Kredit yang diberikan } \\
\hline Kepada bank lain & 0 \\
\hline Kepada pihak kefiga bukan bank & 938.790 \\
\hline \multicolumn{2}{|l|}{ b. Provisi kredt } \\
\hline Kepada bank lain & 0 \\
\hline Kepada pihak ketiga bukan bank & 25.614 \\
\hline \multicolumn{2}{|l|}{ c. Biaya transaksi } \\
\hline i. Surat berharga & 0 \\
\hline \multicolumn{2}{|l|}{ i. Kredit yang dberikan } \\
\hline Kepada bark lain & 0 \\
\hline Kepada pihak kefiga bukan bank & 0 \\
\hline \multicolumn{2}{|l|}{2 Pendapatan lainnya } \\
\hline a. Pendapatan jasa transaksi & 0 \\
\hline b. Keuntungan peniualan valuta asing & 0 \\
\hline c. Keuntungan peniualan surat berharoa & 0 \\
\hline d. Penerimaan kredit yang dhapusbuku & 0 \\
\hline e. Pemulhan PPAP & 0 \\
\hline f Lainnya & 214130 \\
\hline B. Beban Operasional & 1.088 .011 \\
\hline \multicolumn{2}{|l|}{ a. Beban bunga kontraktual } \\
\hline i. Tabungan & 33242 \\
\hline i. Deposito & 583.008 \\
\hline ii Simpanan dari bank lain & 0 \\
\hline Dari Bank Indonesia & 0 \\
\hline Dari Bark Lan & 11322 \\
\hline Dari Phak Ketiga Bukan Bank & 4243 \\
\hline v. Pinjaman Subordinas & 0 \\
\hline vi Lainna & 15.674 \\
\hline
\end{tabular}

\begin{tabular}{|c|c|}
\hline \multicolumn{2}{|l|}{ b. Biaya Transaksi } \\
\hline i. Kepada bank lain & 0 \\
\hline i. Kepada pihak ketiga bukan bark & 0 \\
\hline c. Koreksi atas pendapatan bunga & 0 \\
\hline 2. Beban kerugian restrukturisasi kredt: & 0 \\
\hline \multicolumn{2}{|l|}{ 3. Beban PPAP } \\
\hline a. Surat berharga & 0 \\
\hline b. Penempatan pada bark lain & 2524 \\
\hline \multicolumn{2}{|l|}{ c. Kredt yang diberikan } \\
\hline i. Kepada bank lain & 0 \\
\hline ii. Kepada pihak ketiga bukan bank & 12347 \\
\hline 4. Beban Pemasaraniklan & 2.000 \\
\hline 5. Beban penelitian dan pengembangan & 0 \\
\hline \multicolumn{2}{|l|}{ 6. Beban Administrasi dan Umum } \\
\hline \multicolumn{2}{|l|}{ a. Beban tenaga kerja } \\
\hline ¿ Gail dan upah & 299.368 \\
\hline ii. Honorarium & 20.000 \\
\hline d. Beban penyusutan atas ATI & 19.186 \\
\hline e. Beban amortisasi aset fidak berwujud & 0 \\
\hline f. Beban Premi asuransi & 0 \\
\hline g. Beban pemeliharaan dan perbakikan & 6418 \\
\hline h. Beban barang dan jasa & 48.621 \\
\hline i. Pajak-pajak & 5.936 \\
\hline \multicolumn{2}{|l|}{ 7. Beban lainya } \\
\hline a Kerugian penjualan valuta asing & 0 \\
\hline b. Kerugian penjualan surat berharga & 0 \\
\hline \multirow[t]{2}{*}{ c. Lainya } & 3.501 \\
\hline & 184.846 \\
\hline D. Pendapatan non-operasional & 363 \\
\hline \multicolumn{2}{|l|}{ 1. Keuntungan perivalan } \\
\hline a. Aset telap dan inventaris & 0 \\
\hline b. AYDA & 0 \\
\hline \multicolumn{2}{|l|}{ 2. Pemulhan penurunan nilai } \\
\hline a. Asel telap dan inventaris & 0 \\
\hline b. AYDA & 0 \\
\hline 3. Pendapatan qarti rugi asuransi & 0 \\
\hline
\end{tabular}

Tabel 4 Laporan Laba Rugi

Sumber : PT. BPR Bumidhana, 2017

\begin{tabular}{|c|c|}
\hline 4. Bunga antar kantor & 0 \\
\hline 5. Selisih Kurs & 0 \\
\hline 6. Lainnya & 363 \\
\hline 7. Beban non-operasional & 1.400 \\
\hline \multicolumn{2}{|l|}{ 1. Kerugian penjualan/kehilangan } \\
\hline a. Aset tetap dan inventaris & 0 \\
\hline b. AYDA & 0 \\
\hline \multicolumn{2}{|l|}{ 2. Kerugian penurunan nilai } \\
\hline a. Aset tetap dan inventaris & 0 \\
\hline b. AYDA & 0 \\
\hline 3. Bunga Antar kantor & 0 \\
\hline 4. Selisih kurs & 0 \\
\hline 5. Lainnya & 1.400 \\
\hline F. Laba non-operasional (D-E) & 0 \\
\hline \multirow{2}{*}{$\begin{array}{l}\text { Rugi non-operasional (E-D) } \\
\text { G. Laba tahun berjalan }\end{array}$} & $(1.037)$ \\
\hline & 184.846 \\
\hline Rugi tahun berjalan & $(1.037)$ \\
\hline H. Taksiran Pajak Penghasilan & 0 \\
\hline I. Jumlah laba & 183.809 \\
\hline Jumlah rugi & 0 \\
\hline
\end{tabular}


Pada laporan keuangan dilihat laba tahun berjalan periode 31 Maret 2017 menunjukan angka 183.810.000,- dan total aset sebesar 33.974.796.000,- Dengan total aset yang cukup besar dan laba yang cukup besar diawal tahun tidak menentukan bahwa tingkat kesehatan bank dinyatakan sehat.

Berikut ini adalah Faktor-faktor penilaian tingkat kesehatan bank :

1. Capital (Permodalan)

Faktor yang mempengaruhi penilaian rasio Capital atau Permodalan adalah Rasio jumlah Modal terhadap Aktiva Tertimbang Menurut Resiko (ATMR). Di bawah ini adalah perhitungan ATMR dan Rasio Permodalan pada PT. BPR Bumidhana Periode Maret 2017:

\begin{tabular}{|c|c|c|c|}
\hline \multirow[b]{2}{*}{ KETERANGAN } & \multicolumn{3}{|c|}{ Mar-17 } \\
\hline & Nominal & $\begin{array}{l}\text { Bobot } \\
\text { Resiko }\end{array}$ & ATMR \\
\hline 1 Kas & 31.702 & $0 \%$ & $\div$ \\
\hline 2. Sertirikatbankindonesia & & $0 \%$ & \\
\hline $\begin{array}{l}\text { 3. Kredit yang dijamin dengan } \\
\text { uang kas, valas, emas, mata } \\
\text { uang emas serta deposito } \\
\text { berjangka, dan tabungan } \\
\text { padabankybs. }\end{array}$ & 22.296 .298 & $0 \%$ & - \\
\hline $\begin{array}{l}\text { 4. Kredit KepadaPemerintah } \\
\text { Pusat }\end{array}$ & & $0 \%$ & $=$ \\
\hline $\begin{array}{l}\text { 5. Gro, deposito berjangka, } \\
\text { sertifikat deposito, tabungan } \\
\text { serta tagihan lainnya } \\
\text { kepada bank lain (ABA) }\end{array}$ & 8.069 .768 & $20 \%$ & 1.613 .954 \\
\hline $\begin{array}{l}\text { 6. Kredit kepada atau yang } \\
\text { dijamin oleh Bank iain atau } \\
\text { Pemda }\end{array}$ & & $20 \%$ & + \\
\hline $\begin{array}{l}\text { 7. KFR yang dijamin dg Hak } \\
\text { Tanggungan I (utk dihuni) }\end{array}$ & & $40 \%$ & $=$ \\
\hline $\begin{array}{l}\text { 8. Kredit kepada atau yang } \\
\text { dijamin oleh BUMN/BUMD }\end{array}$ & & $50 \%$ & $=$ \\
\hline $\begin{array}{l}\text { 9. Kredit kepada Pegawail } \\
\text { Pensiunan }\end{array}$ & & & \\
\hline $\begin{array}{l}\text { Pensiunan } \\
10 \text { Kreditkepada UMK }\end{array}$ & $\frac{785.867}{2.355 .231}$ & $\frac{50 \%}{85 \%}$ & $\frac{392.933}{2.007 .946}$ \\
\hline $\begin{array}{l}\text { 11. Tagihan kepada atau } \\
\text { tagihan yg dijamin oleh atau } \\
\text { surat berharga yg diterbitkan } \\
\text { atau dijamin oleh: }\end{array}$ & & & $=$ \\
\hline a. Perorangan & & $100 \%$ & $=$ \\
\hline b. Koperasi & & $100 \%$ & $=$ \\
\hline $\begin{array}{l}\text { c. Kelompok dan } \\
\text { Perugahaan lainnya }\end{array}$ & & $100 \%$ & - \\
\hline 12. Aktiva tetap dan & & & \\
\hline inventaris (Nilai Buku) & 305.445 & $100 \%$ & 305.445 \\
\hline $\begin{array}{l}\text { 13. Asef lainnya selain } \\
\text { tersebut diatas }\end{array}$ & 291.021 & $100 \%$ & 291.021 \\
\hline Jumlah ATMR & 34.135 .332 & & $4.605,299$ \\
\hline
\end{tabular}

Tabel 5 Aktiva Tertimbang Menurut Resiko Sumber : PT. BPR Bumidhana, 2017

ATMR dihitung dari bobot resiko yang telah ditentukan Bank Indonesia dikalikan dengan nilai nominal pada pos-pos Aktiva, tidak termasuk Penyisihan Penghapusan Aset Produktif, Penyisihan Provisi Kredit dan Akumulasi Penyusutan. Pada neraca per maret 2017 apat terlihat bahwa jumlah total modal adalah Rp. 2.597.701,- (dalam ribuan rupiah) yang terdiri dari modal inti $\mathrm{Rp}$. 2.572.846 dan modal pelengkap sebesar Rp. 24.855,-. Sementara modal minimumyang dipersaratkan (8\% X ATMR) yaitu Rp. 368.424,- $\quad$ sehingga diketahui bahwa PT. Bumidhana memiliki kelebihan moal sebesar Rp. 
2.204.422,- dari uraian tersebut dapat dihitung rasio modal (CAR= Modal/ATMR X 100\%) yaitu 56,4\%.

2. Asset Quality (Kualitas Aktiva Produktif)

Faktor Kualitas Aktiva Produktif (KAP) terdiri dari dua komponen, yaitu rasio KAP dan rasio Penyisihan Penghapusan Aktiva Produktif (PPAP). Rasio KAP dihitung dari rasio yang diklasifikasikan (APYD) terhadap jumlah Aktiva Produktif. Aktiva Produktif berupa kredit yang diberikan dan penempatan pada bank lain diluar giro. Berikut ini adalah tabel rasio KAP pada PT. BPR Bumidhan periode Maret 2017:

\begin{tabular}{|c|c|c|c|}
\hline \multirow[b]{2}{*}{ KETERANGAN } & \multicolumn{3}{|c|}{ Mar-17 } \\
\hline & Kredit & $\begin{array}{c}\text { Penempatan pada } \\
\text { Bank Lain Selain } \\
\text { Giro }\end{array}$ & Jumlah \\
\hline \multicolumn{4}{|c|}{ 1. AKTIVA PRODUKTIF } \\
\hline - Lancar & 24.022 .293 & 3.151 .249 & 27.173 .542 \\
\hline - Kurang lancar & 210.988 & & 210.988 \\
\hline - Diragukan & 124.450 & & 124.450 \\
\hline - Macet & 1.079 .665 & & 1.079 .665 \\
\hline JUMLAH & 25.437 .395 & 3.151 .249 & 28.588 .644 \\
\hline \multicolumn{4}{|c|}{ 2. AKTIVA PRODUKTIF YG DIKLASIFIKASIKAN } \\
\hline - Kurang Lancar(50\%) & 105.494 & & 105.494 \\
\hline - Diragukan $(75 \%)$ & 93.338 & & 93.338 \\
\hline - Macet $\quad(100 \%)$ & 1.079 .665 & & 1.079 .665 \\
\hline JUMLAH & 1.278 .496 & & 1.278 .496 \\
\hline \multirow{2}{*}{ Rasio KAP } & \multicolumn{2}{|c|}{ Aktiva Produktif Yg Diklasifikasikan } & \multirow[t]{2}{*}{$4,47 \%$} \\
\hline & \multicolumn{2}{|c|}{ Aktiva Produktif } & \\
\hline
\end{tabular}

Tabel 6 Kualitas Aktiva Produktif

Sumber : PT. BPR Bumidhana

Berdasarkan ketentuan Bank Indonesia Rasio KAP dikatakan sehat apabila rasio kurang dari 10,35\%, sedangkan rasio KAP pada PT. BPR Bumidhana adalah 4,47\% maka rasio KAP BPR Bumidhana dinyatakan sehat. Berikut ini perhitungan rasio KAP BPR Bumidhana:

$$
\begin{aligned}
\text { Rasio KAP } & =\frac{\mathrm{APYD}}{\mathrm{AP}} \times 100 \% \\
& =\frac{1.278 .496}{28.588 .644} \times 100 \%=4,47 \%
\end{aligned}
$$

Faktor kedua yang terdapat pada komponen Kualitas Aktiva Produktif adalah Rasio PPAP. PPAP merupakan antisipasi kerugian yang dibentuk bank atas kemungkinan tidak tertagihnya Aktiva Produktif, PPAPWD merupakan antisipasi kerugian yang seharusnya dibentuk bank berdasarkan kolektabilitas aktiva produktif yang perhitungannya sudah ditentukan oleh Bank Indonesia. 


\begin{tabular}{|c|c|c|c|}
\hline \multicolumn{4}{|c|}{$\begin{array}{ll}\text { PPAPWD } & \text { (setelah diperhitungkan agunan) }\end{array}$} \\
\hline - Lancar $(0,5 \%)$ & 9.099 & 15.756 & 24.855 \\
\hline - Kurang lancar (10\%) & 14.139 & & 14.139 \\
\hline - Diragukan (50\%) & - & & - \\
\hline - Macet $(100 \%)$ & 50.784 & & 50.784 \\
\hline JUMLAH & 74.021 & & 89.778 \\
\hline \multicolumn{3}{|l|}{ PPAP Yang dibentuk BPR } & 89.778 \\
\hline
\end{tabular}

\begin{tabular}{|l|c|c|}
\hline \multirow{2}{*}{ Rasio PPAP } & Penyisihan Penghapusan Aktiva Produktif & \multirow{2}{*}{$100 \%$} \\
\cline { 2 - 2 } & PPAP Yg Wajib Dibentuk & \\
\hline
\end{tabular}

Tabel 7 Penyisihan Penghapusan Aktiva Produktif Sumber : PT. BPR Bumidhana

Rasio PPAP dikatakan sehat apabila rasio lebih besar dari $81 \%$, sedangkan rasio PPAP pada PT. BPR Bumidhana adalah sebesar 100\% maka rasio PPAP PT. BPR Bumidhana dinyatakan sehat.

3. Manajemen

Faktor rasio Manajemen didasarkan atas penilaian terhadap manajemen umum dan manajemen resiko, dibawah ini adalah hasil penilaian manajemen umum dan resiko pada PT. BPR Bumidhana:

\begin{tabular}{|c|c|c|}
\hline NAMA RASIO & NILAI ACUAN & NILAI (Ratio) \\
\hline \hline CAR & $>=8.00$ & 56,41 \\
\hline KAP & $<=10.35$ & 4,47 \\
\hline PPAP & 100 & 100,00 \\
\hline Umum \& Resiko & $81-100$ & 53,00 \\
\hline ROA & $>=1.215$ & 0,55 \\
\hline BOPO & $<=93.25$ & 85,48 \\
\hline CR & $>=4.05$ & 16,07 \\
\hline LDR & $<=94.75$ & 75,56 \\
\hline
\end{tabular}

Tabel 8 Rasio Manajemen Umum dan Resiko Sumber : PT. BPR Bumidhana, 2017

Dari tabel di atas terlihat bahwa rasio penilaian untuk manajemen umum dan resiko adalah 53, sedangkan berdasarkan ketentuan dari Bank Indonesia jika hasil penilaian 53 maka dinyatakan Kurang Sehat. Hal ini menunjukan bahwa kinerja manajemen pada PT. BPR Bumidhana tidak baik bagi manajemen kredit maupun manajemen biaya operasional.

4. Earnings (Rentabilitas) 
Rasio Earnings atau Rentabilitas terdiri dari dua komponen yaitu rasio laba terhadap rata-rata aktiva dalam 12 bulan terakhir atau disebut dengan Return of Assets (ROA) dan rasio biaya operasional terhadap pendapatan operasional dalam 12 bulan terakhir (BOPO). Di bawah ini tabel perhitungan ROA dan BOPO periode Maret 2017 pada PT. BPR Bumidhana:

\begin{tabular}{|c|c|}
\hline Bulan & Asset 2017 \\
\hline JANUARI & 32.535 .734 \\
\hline PEBRUARI & 34.113 .142 \\
\hline MARET & 33.974 .796 \\
\hline \multicolumn{2}{|c|}{ APRIL - DESEMBER BELUM DAPAT DISAJIKAN } \\
\hline TOTAL & 100.623 .672 \\
\hline $\begin{array}{l}\text { Laba (Rugi) Sebelum Pajak } \\
\text { Maret }\end{array}$ & 183.809 \\
\hline Rata-rata Aset & 33.541 .224 \\
\hline ROA & $0,55 \%$ \\
\hline Beban Operasional & 1.088 .011 \\
\hline Pendapatan Operasional & 1.272 .857 \\
\hline BOPO & $85,48 \%$ \\
\hline
\end{tabular}

Tabel 9 Rasio ROA dan BOPO

Sumber : PT. BPR Bumidhana, 2017

Penilaian rasio ROA menurut ketentuan Bank Indonesia jika rasio ROA kurang dari $0,765 \%$ maka dinyatakan tidak sehat, sedang rasio ROA pada BPR Bumidhana diperoleh sebesar 0,55\% maka rasio ROA BPR Bumidhana Tidak Sehat. Dibawah ini adalah rumus perhitungan ROA pada PT. BPR Bumidhana:

$$
\begin{aligned}
\text { ROA } & =\frac{\text { Laba/Rugi sebelum Pajak }}{\text { Rata-rata Aktiva }} \times 100 \% \\
& =\frac{183.809 \times 100 \%=0,55 \%}{33.541 .224}
\end{aligned}
$$

Terlihat dengan jumlah Aktiva yang besar namun hanya menghasilkan laba sebesar 183.809, jika dilihat pada laporan neraca jumlah aktiva terbesar adalah pos kredit yaitu sebesar 25.437.395, hal ini berarti pos kredit tidak menghasilkan laba yang optimal karena terdapat kredit bermasalah di dalam pos tersebut.

Berdasarkan ketentuan dari Bank Indonesia jika rasio BOPO kurang dari 93,52\% maka dinyatakan sehat. Rasio BOPO pada BPR Bumidhana adalah sebesar 85,48\%, maka rasio BOPO pada BPR Bumidhana dinyatakan sehat. Di bawah ini adalah rumus perhitungan BOPO pada BPR Bumidhana:

$$
\text { Rasio BOPO }=\frac{\text { Biaya Operasional }}{\text { Pendapatan Operasional }}
$$




$$
=\frac{1.088 .011}{1.272 .857} \times 100 \%=85,48 \%
$$

\section{Liquidity (Likuiditas)}

Faktor rasio likuiditas terdiri dari dua komponen yaitu rasio kecukupan alat likuid (Cash Ratio) dan rasio kredit terhadap dana yang diterima atau disebut Loan to Deposito Ratio. Dari laporan neraca PT. Bumidhana dapat dilihat total jumlah alat likuid ( Kas \& penempatan pad bank lain adalah Rp. 4.951.470,(dalam ribuan rupiah). Sedangkan total hutang lancar (kewajiban segera dan simpanan pihak ketiga) adalah Rp. 30.812.870,- Rasio Kas dikatakan sehat jika rasio lebih besar dari 4,05\%, rasio kas dihitung dari Jumlah Kas, Giro dan Tabungan antar Bank Aktiva yang dikurang dengan Tabungan antar Bank Pasiva terhadap jumlah dari kewajiban segera, tabungan dan deposito. Di bawah ini perhitungan Rasio Kas pada PT. BPR Bumidhana:

$$
\begin{aligned}
& C R=\underline{\text { Kas + Giro (Tab. ABA - Tab. ABP) }} \times 100 \% \\
& \text { Kewajiban Segera+Tab+Dep } \\
& =\underline{31.702+4.918 .519+(1.249-0)} \times 100 \% \\
& \text { 84.191+2.636.967+28.091.712 } \\
& =\quad \frac{4.951 .470}{812870}=16,07 \%
\end{aligned}
$$

Dari perhitungan rasio kas diatas menunjukan bahwa rasio kas pada PT. BPR Bumidhana dinyatakan Sehat. Dibawah ini perhitungan rasio likuiditas lainnya yaitu rasio Loan to Deposito Ratio (LDR) pada PT. BPR Bumidhana:

\begin{tabular}{|l|c|}
\hline \multicolumn{1}{|c|}{ Uraian } & Mar-17 \\
\hline DANA YANG DITERIMA & \\
1. Simpanan pihak III & 2.636 .967 \\
$\quad$ a. Tabungan & 28.091 .712 \\
b. Deposito & 113.924 \\
2. Pinjaman diterima bukan dari bank lebih dari 3 & \\
bulan & 251.136 \\
3. Deposito dan pinjaman dari bank, lebih dari 3 & - \\
bulan & 2.572 .846 \\
4. Modal Pinjaman & 33.666 .584 \\
5. Modal Inti & \\
JUMLAH DANA YANG DITERIMA & 25.437 .395 \\
KREDIT & 25.437 .395 \\
1. Kredit yang diberikan & $\mathbf{7 5 , 5 6 \%}$ \\
JUMLAH KREDIT & \\
LDR (Rasio kredit terhadap Dana yang diterima) & \\
\cline { 2 - 2 }
\end{tabular}

Tabel 10 Loan To Deposito Ratio (LDR)

Sumber : PT. BPR Bumidhana, 2017

Dibawah ini rumus perhitungan rasio LDR pada PT. BPR Bumidhana:

$$
\text { LDR }=\frac{\text { Jumlah Kredit Yang Diberikan X X 100\% }}{\text { Dana Yang Diterima }}
$$




$$
=\frac{25.437 .395}{33.666 .584} \times 100 \%=75,56 \%
$$

Dari perhitungan rasio LDR diatas menunjukan bahwa rasio LDR pada PT. BPR Bumidhana dinyatakan sehat karena berdasarkan ketentuan dari Bank Indonesia rasio LDR dinyatakan sehat apabila rasio kurang dari 94,75\% sedangkan rasio LDR pada PT. BPR Bumidhana adalah 75,56\%.

\section{KESIMPULAN}

Berdasarkan penelitian atas analisis terhadap Kesehatan Bank dengan Metode CAMEL pada PT. BPR Bumidhana maka dapat diambil kesimpulan sebagai berikut:

1. Berdasarkan pembahasan pada bab sebelumnya Faktor-faktor Non Performing Loan pada PT. BPR Bumidhana adalah kredit bermasalah pada BPR, jumlah kredit yang disalurkan oleh BPR, dan PPAP yang telah dibentuk oleh BPR. Kredit bermasalah pada BPR dikategorikan menjadi Kredit dengan kolektabilitas Lancar dengan tunggakan, Kurang Lancar, Diragukan dan Macet.

2. Berdasarkan Laporan Tingkat Kesehatan Bank pada PT. BPR Bumidhana periode 31 Maret 2017 pada perhitungan rasio Non Performing Loan, rasio NPL PT. BPR Bumidhana dinyatakan tidak sehat karena melebihi batas maksimal 5\% dari ketentuan Bank Indonesia yaitu sebesar 5,31\%. Sedangkan penilaian tingkat kesehatan Bank dari faktor-faktor rasio CAMEL, nilai TKS PT. BPR Bumidhana sebesar $87,48 \%$ berada pada nilai kredit 81-100\% dengan predikat sehat. Semua rasio-rasio dari faktor CAMEL mendapat predikat sehat kecuali Rasio Manajeman Umum dan Resiko dengan nilai rasio sebesar 53\% pada posisi nilai acuan 51-66\% dinyatakan Kurang Sehat serta rasio ROA pada faktor Rentabilitas dengan nilai $0,55 \%$ pada posisi nilai acuan kurang dari $0,765 \%$ dengan predikat Tidak Sehat.

\section{Daftar Pustaka}

Budi santoso, Totok,dan Nuritomo, Bank dan Lembaga Keuangan Lain, Edisi 3, Jakarta,Salemba Empat, 2014

Chariri, A. 2009. "Landasan Filsafat dan Metode Penelitian Kualitatif", Paper disajikan pada Workshop Metodologi Penelitian Kuantitatif dan Kualitatif, Laboratorium Pengembangan Akuntansi (LPA), Fakultas Ekonomi 
Universitas Diponegoro Semarang, 31 Juli - 1, Agustus 2009

Iskandar,Syamsu, Akuntansi Perbankan Dalam Rupiah dan ValutaAsing, Jakarta: Salemba Empat, 2013.

Kasmir, Bank dan Lembaga Keuangan Lainnya,Depok: Rajawali Pers,2013.

Keputusan Presiden Republik Indonesia Nomor 38 mengenai Keberadaan dan Kegiatan Usaha BPR.

Pandia,Frianto,ManajemenPerbankan, Jakarta: Salemba Empat, 2012

Peraturan Bank Indonesia Nomor 13/26/PBI/2011 tentang Penilaian Kualitas Aktiva Produktif

Peraturan Bank Indonesia Nomor 8/26/PBI/2006 tanggal 8 November 2006 tentang Bank Perkreditan Rakyat

Peraturan Bank Indonesia Nomor 6/10/PBI/2004 tentang Sistem Penilaian Tingkat Kesehatan pada Bank Umum

Rivai,V et.al.Commercial Bank Management Manajemen Perbankan Dari Teori Ke Praktik, Jakarta: Rajawali Pers,2013

Surat Keputusan Direktur Bank Indonesia Nomor 30/12/KEP/DIR tanggal 30 April 1997 tentang Tatacara Penilaian Tingkat Kesehatan Bank Perkreditan Rakyat

Tim Pedoman Akuntansi Bank Perkreditan Rakyat Bank Indonesia, Pedoman Akuntansi Bank Perkreditan Rakyat, Jakarta: IAI, 2010

Undang - Undang Negara Republik Indonesia Nomor 10 Tahun 1998 tanggal 10 November 1998 tentang Perbankan

Undang - undang Nomor 24 tahun 2004 tanggal 22 September 2004 tentang Lembaga Penjamin Simpanan. 